\title{
An Evaluation of MODIS Global Evapotranspiration Product as Satellite-Based Evapotranspiration Data for Supporting Precision Agriculture in West Papua - Indonesia
}

\author{
Arif Faisol ${ }^{1}$, Indarto Indarto ${ }^{2 *}$, Elida Novita ${ }^{2}$ and Budiyono ${ }^{3}$ \\ ${ }^{1}$ Faculty of Agricultural Technology - University of Papua, Jln. Gunung Salju Amban, Manokwari, West Papua \\ 98314, Indonesia. ${ }^{2}$ Faculty of Agricultural Technology - University of Jember, Jln. Kalimantan No 37, Jember \\ 68121, Indonesia. ${ }^{3}$ Faculty of Agriculture - University of Papua, Jln. Gunung Salju Amban, Manokwari, West \\ Papua 98314, Indonesia, *e-mail: indarto.ftp@unej.ac.id
}

Received February 25, 2020; Revised November 24, 2020; Accepted 25 November 2020

\begin{abstract}
Precision Agriculture has been a significant issue since the middle of the 1980s. Evapotranspiration is one of the main parameters in precision agriculture to analyze real water needs in the agriculture area and managing water resources. Traditionally evapotranspiration estimates by directly measured methods, i.e., lysimeter, pan-evaporation, eddy covariance, Bowen ratio, soil water, and climate data analysis. These methods are expensive techniques with low spatial representativeness. The utilization of remote sensing technology is expected to be an alternative solution for providing evapotranspiration data with a cost-effective and high spatial representative. This research aims to evaluate the MODIS global evapotranspiration as satellite-based evapotranspiration in estimating evapotranspiration in West Papua. Four (4) statistical parameters, i.e., mean error (ME), root means square error (RMSE), relative bias (RB), and mean bias factor (MBF), are using for evaluation. The research showed that MODIS global evapotranspiration was overestimated in estimating evapotranspiration in West Papua. However, MODIS global evapotranspiration has an acceptable accuracy in estimating evapotranspiration in West Papua indicated by $\mathrm{ME}=$ $0.66 \mathrm{~mm} /$ day, $\mathrm{RMSE}=0.94 \mathrm{~mm} / \mathrm{day}, \mathrm{RB}=0.27$, and $\mathrm{MBF}=0.81$. Therefore, MODIS global evapotranspiration can be used as an alternative solution for providing evapotranspiration data in West Papua with a cost-effective.
\end{abstract}

Keywords: Evapotranspiration, MODIS global evapotranspiration product, satellite-based evapotranspiration, precision agriculture

\section{INTRODUCTION}

The precision agriculture issue was introduced in the middle of the 1980s. The concept of precision agriculture is to identify within-field variability and manage that variability (Zhang 2016). Precision agriculture aims to improve site-specific agricultural decision-making through collection and analysis of data, formulation of site-specific management recommendations, and implementation of management practices (Thenkabail 2016) to increase the profitability of crop production reduce the negative environmental impact (Pierce and Nowak 1999).

Evapotranspiration is one of the main parameters in precision agriculture. It uses to analyze

J Trop Soils, Vol. 26, No. 1, 2021: 43-49

ISSN 0852-257X ; E-ISSN 2086-6682 real water needs in the agriculture area. Therefore accurate and detailed evapotranspiration information is crucial to managing water resources. Traditionally evapotranspiration estimates by directly measured methods, i.e., lysimeter, pan-evaporation, eddy covariance, Bowen ratio, soil water balance (Allen et al. 1998), and climate data analysis. However, these methods are expensive techniques with low spatial representativeness (Allen et al. 1998). Direct-measurement methods are suitable to estimate ET at field-scale or an area of fewer than 10 hectares (Allen et al. 1998), and climate data analysis suitable to estimate evapotranspiration for an area of $\pm 5000 \mathrm{~km}^{2}$ or equivalent to a region having a radius of $\sim 40 \mathrm{~km}$ from the climatology station (WMO 2008).

The utilization of remote sensing technology is expected to be an alternative solution to estimate evapotranspiration with cost-effective and high 
spatial coverage. Guzinski and Nieto's research shows that remote sensing technology can be used to estimate high-resolution evapotranspiration at the field scale with $85 \%$ accuracy compared with local meteorological observation and $81 \%$ accuracy compared with climate data analysis (Guzinski and Nieto 2019). Other studies show that remote sensing technology can estimate evapotranspiration at acceptable results (Nouri et al. 2017; Li et al. 2017) and do the goodness of fit compared with meteorological data analysis (Bonemberger et al. 2018). Ceron et al. 2015 reported that the evapotranspiration estimation based on remote sensing is better during the critical dry season when cloud cover is low (Ceron et al. 2015). However, evapotranspiration estimation based on remote sensing technology overestimated during the rainy season and underestimated for the dry season (Junior et al. 2013).

MODIS global evapotranspiration product is a satellite image-based evapotranspiration released by the National Aeronautics Space Administration (NASA) with $500 \mathrm{~m}$ of spatial resolution and 8-day temporal resolution. Several institutions in the world using MODIS global evapotranspiration for providing evapotranspiration data, i.e., The European Space Agency (ESA), US Geological Survey (USGS), and Department of Civil Engineering - Indian Institute of Science.
Some studies conducted by Mu et al. (2011); Kim et al. (2012); Shekar and Nandagiri (2016); Miranda et al. (2017); and Aguilar et al. (2018) show that MODIS global evapotranspiration product can estimate actual evapotranspiration with reasonable accuracy. Furthermore, Jiang et al. (2004), Courault et al. (2005), and Kalma et al. (2008) show that deviation of MODIS global evapotranspiration is between $10 \%$ - to $30 \%$ compared to measurement and observation.

This research aims to evaluate the MODIS global evapotranspiration product in estimating evapotranspiration in West Papua based on the above conditions.

\section{MATERIALS AND METHODS}

This research was conducted in West Papua Indonesia. Figure 1 shows the research location. The main stages of this research are data inventory, evapotranspiration data extraction, and data evaluation.

\section{Data Inventory}

As many as 188 scenes, MODIS global evapotranspiration products periods of 2010 to 2019 were collected. Furthermore, daily climate data recording periods of 2010 to 2019 from meteorological stations located at South Manokwari, Sorong, and Fakfak are also collected.

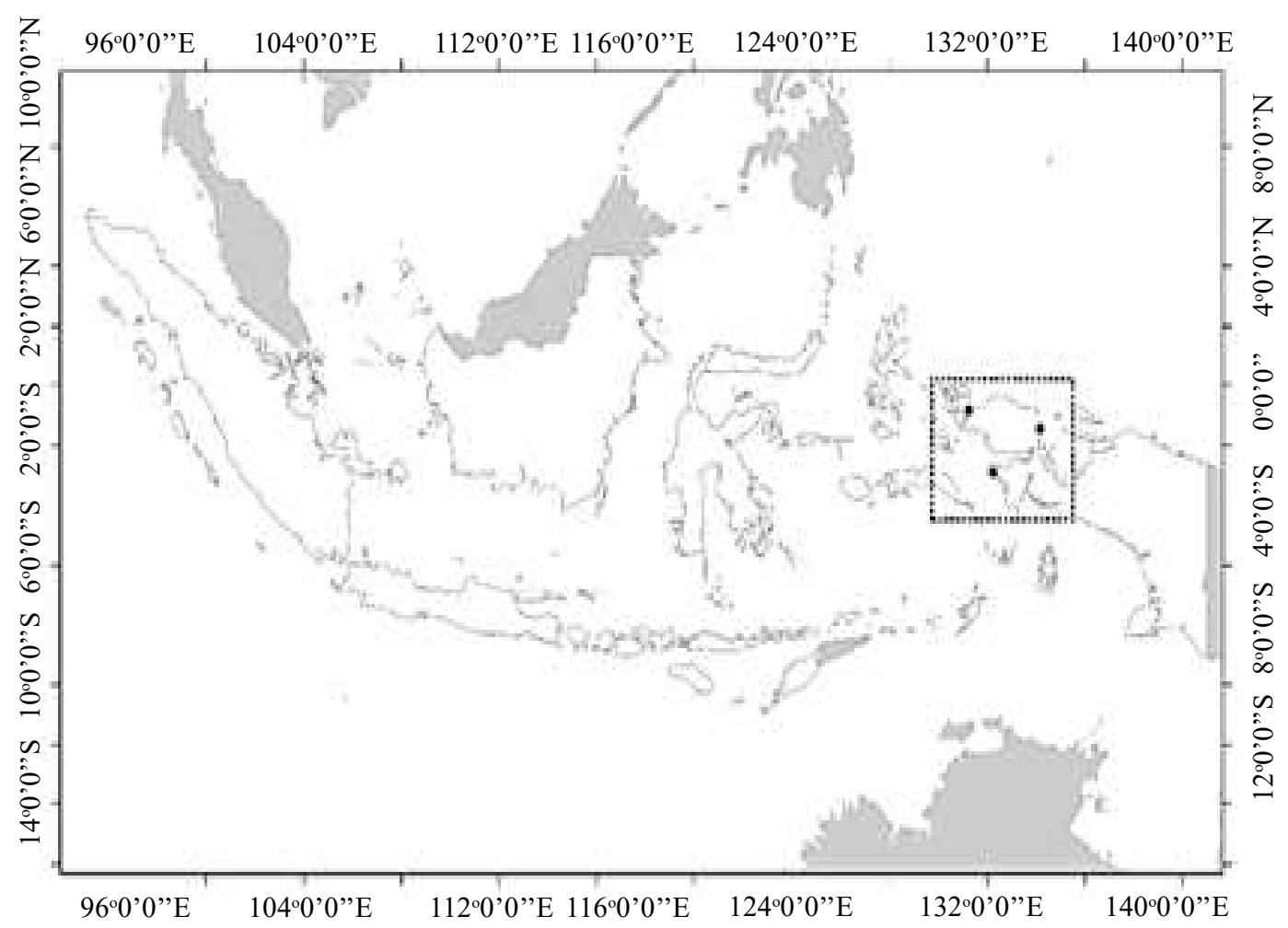

Figure 1. Research location. Study area: $\square$, other country: $\square$, meteorological station: 


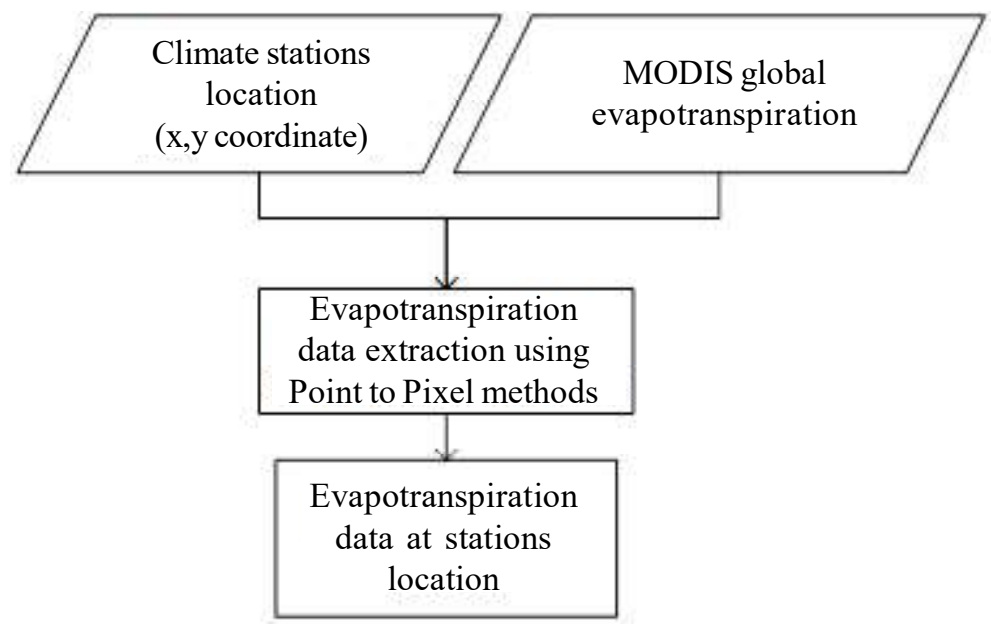

Figure 2. Procedure to extract evapotranspiration data from MODIS global evapotranspiration

\section{Evapotranspiration Data Extraction}

The evapotranspiration data is extracted using point to pixel methods. Figure 2 shows the procedure to extract evapotranspiration data from MODIS global evapotranspiration.

MODIS global evapotranspiration using Penman-Monteith methods in estimating evapotranspiration (Mu et al. 2013). Daily meteorological data and 8-day remotely sensed vegetation is used as inputs. Figure 3 shows the general computation of MODIS global evapotranspiration product.

\section{Evaluation of MODIS Global Evapotranspiration}

The purpose of this stage is to compare evapotranspiration data from MODIS global evapotranspiration with climate data analysis. The four (4) statistical parameters, i.e., mean error (ME), root means square error (RMSE), relative bias (RB), and mean bias factor (MBF), are using for evaluation with the following equations:

$$
\begin{aligned}
& \text { ME }=\frac{1}{n} \sum_{i=1}^{n}(y i-x i) \\
& \text { RB }=\frac{\sum_{i=1}^{n}(y i-x i)}{\sum_{i=1}^{n} x i} \\
& \text { MBF }=\frac{\sum_{i=1}^{n} x i}{\sum_{i=1}^{n} y i} \\
& \text { RMSE }=\sqrt{\frac{1}{n}} \sum_{i=1}^{n}(y i-x i)^{2}
\end{aligned}
$$

Where:

$\mathrm{CC}$ is correlation coefficient, $\mathrm{ME}$ mean error $\left(\mathrm{mm} \cdot \mathrm{day}^{-1}\right), \mathrm{RB}$ relative bias, MBF mean bias factor, RMSE root mean square error $\left(\mathrm{mm}^{\mathrm{day}}{ }^{-1}\right)$, yi satellite

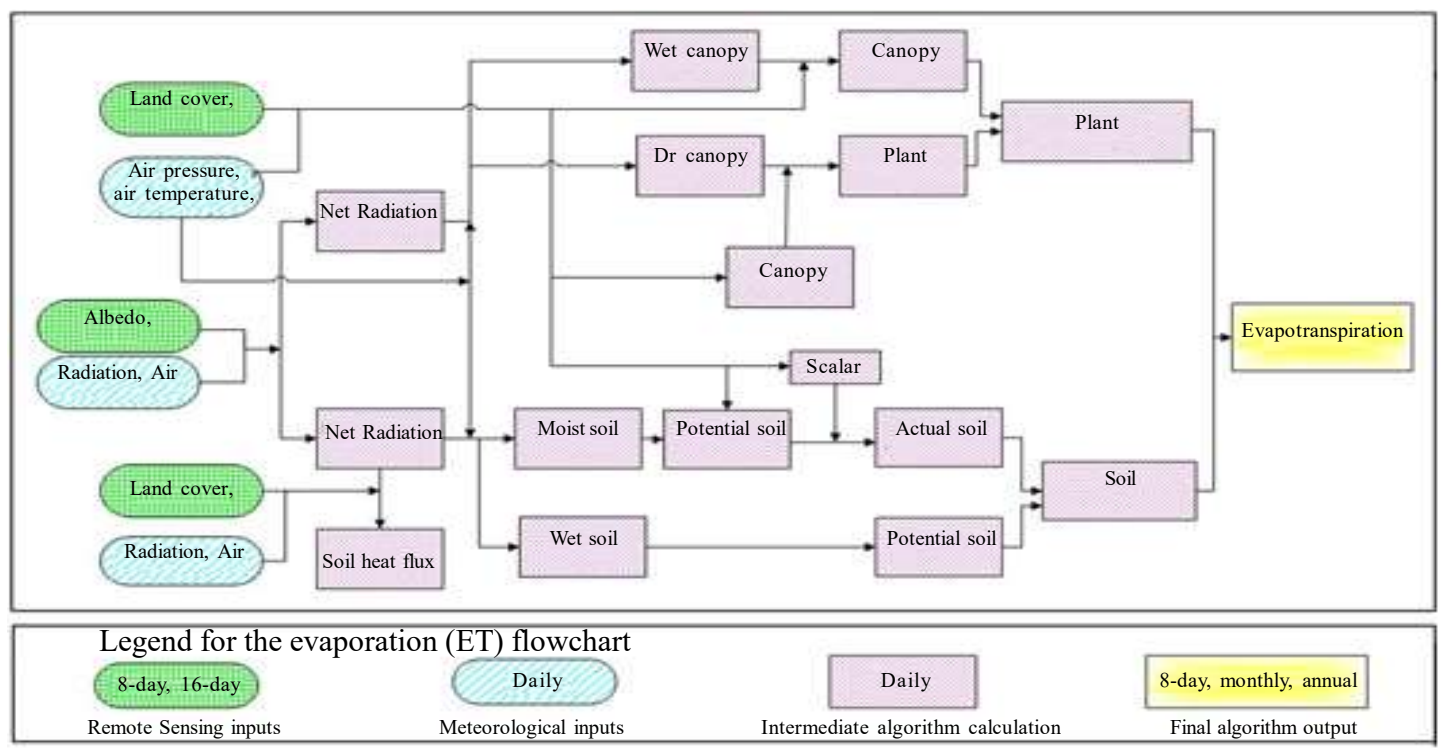

Figure 3. General computation of MODIS global evapotranspiration product (Mu et al. 2013). 

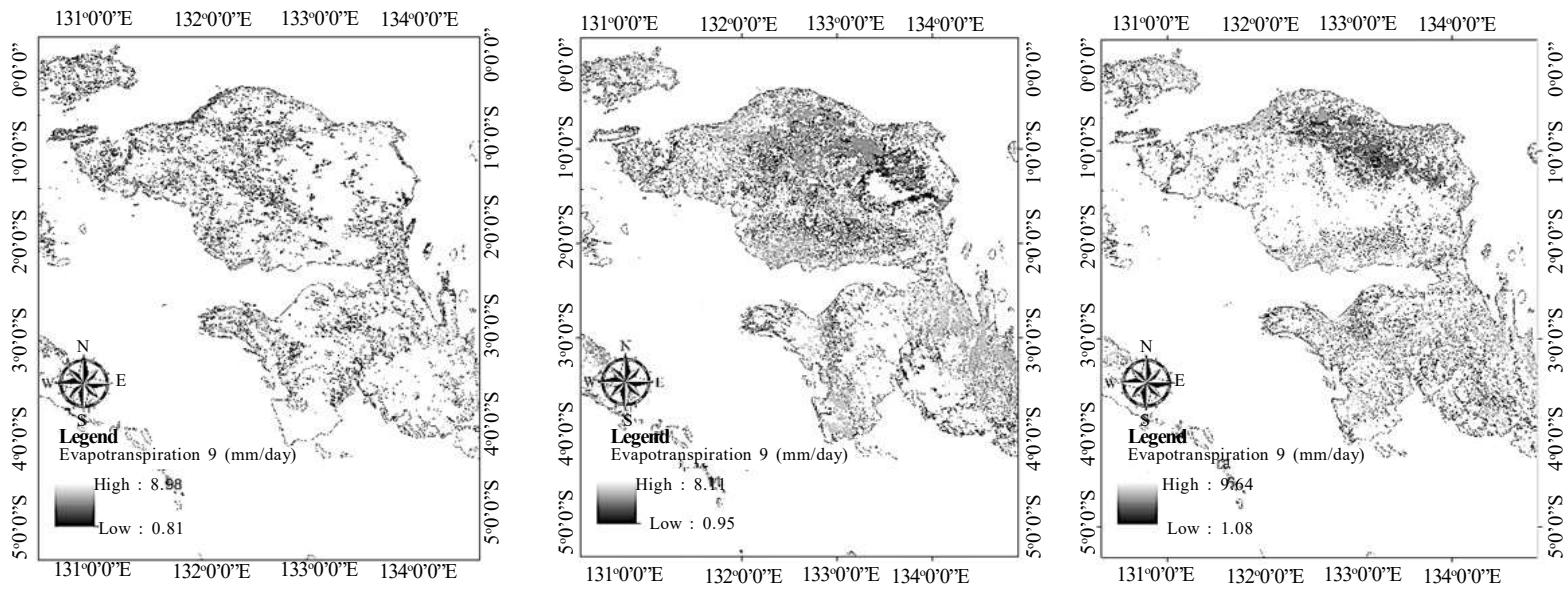

Figure 4. Evapotranspiration data distribution in West Papua based on MODIS global evapotranspiration: (a) 10 June 2017, (b) 14 September 2018, (c) 13 August 2019.

evapotranspiration estimate $\left(\mathrm{mm}^{\mathrm{day}}{ }^{-1}\right), \bar{y}$ averaged satellite evapotranspiration $\left(\mathrm{mm} \cdot \mathrm{day}^{-1}\right)$, xi climate data evapotranspiration $\left(\mathrm{mm} \cdot \mathrm{day}^{-1}\right), \overline{x z}$ averaged climate data evapotranspiration $\left(\mathrm{mm}^{-d a y^{-1}}\right), \mathrm{SD}_{\mathrm{yi}}$ standard deviation of satellite evapotranspiration $\left(\mathrm{mm} \cdot \mathrm{day}^{-1}\right)$, $\mathrm{SD}_{\mathrm{xi}}$ standard deviation of climate data evapotranspiration $\left(\mathrm{mm}^{\mathrm{day}}{ }^{-1}\right)$, and $\mathrm{n}$ amount of data. The prefect value of mean error $(\mathrm{ME})=0$, relative

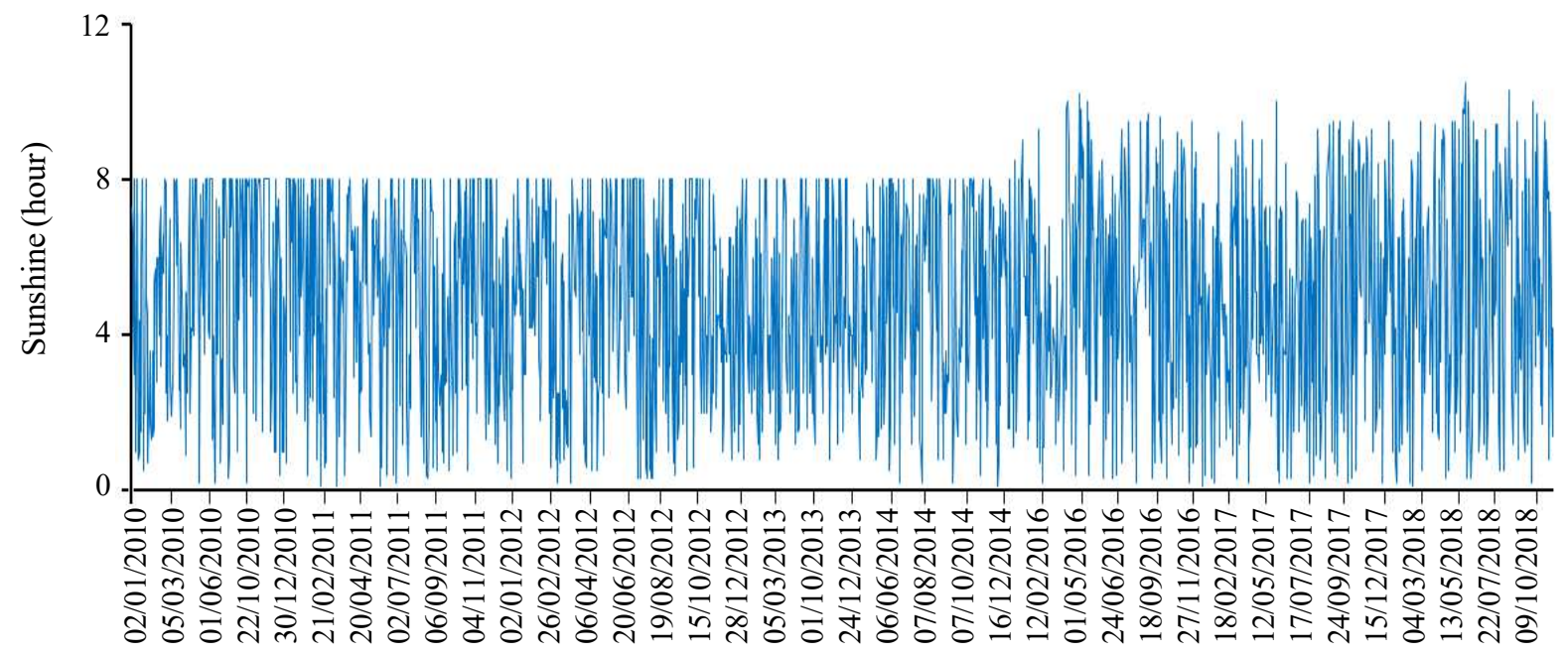

Figure 5. Sunshine duration recording in Ransiki stations - South Manokwari.

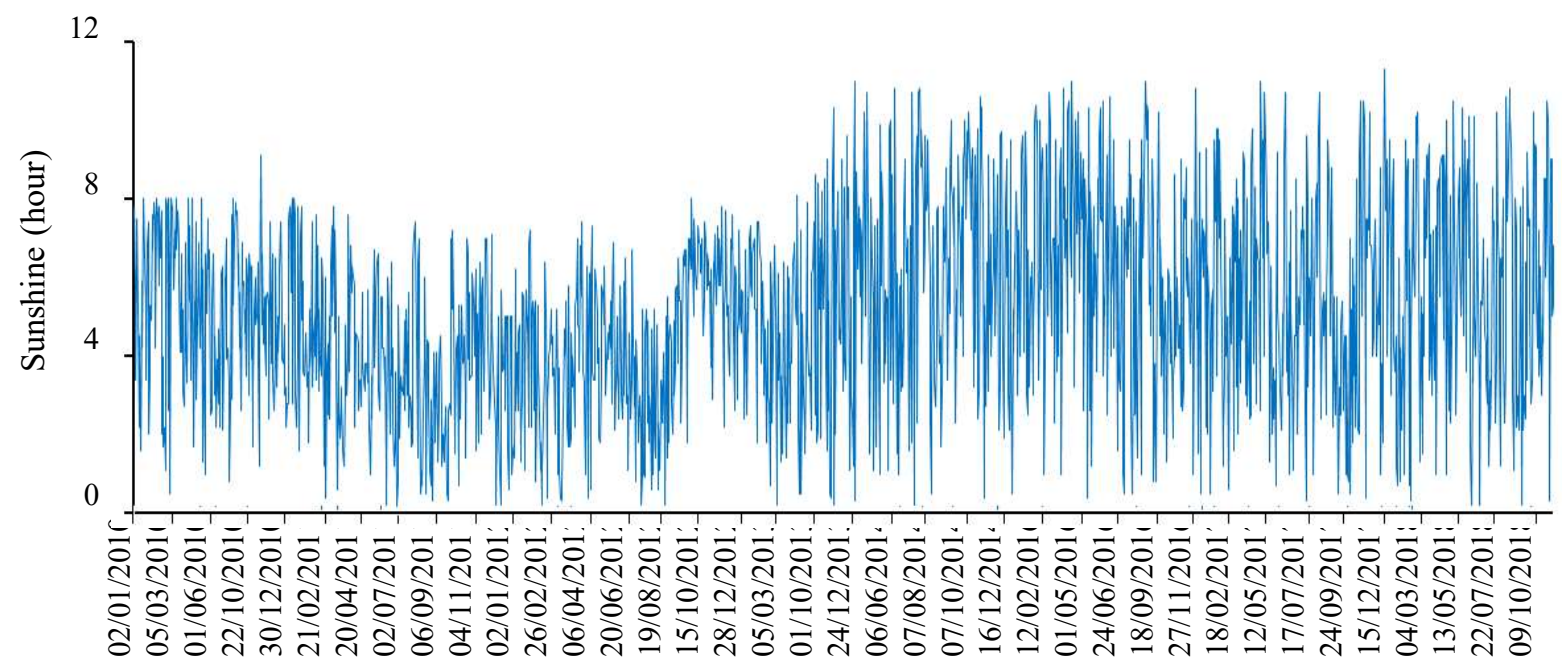

Figure 6. Sunshine duration recording in Seigun stations - Sorong. 


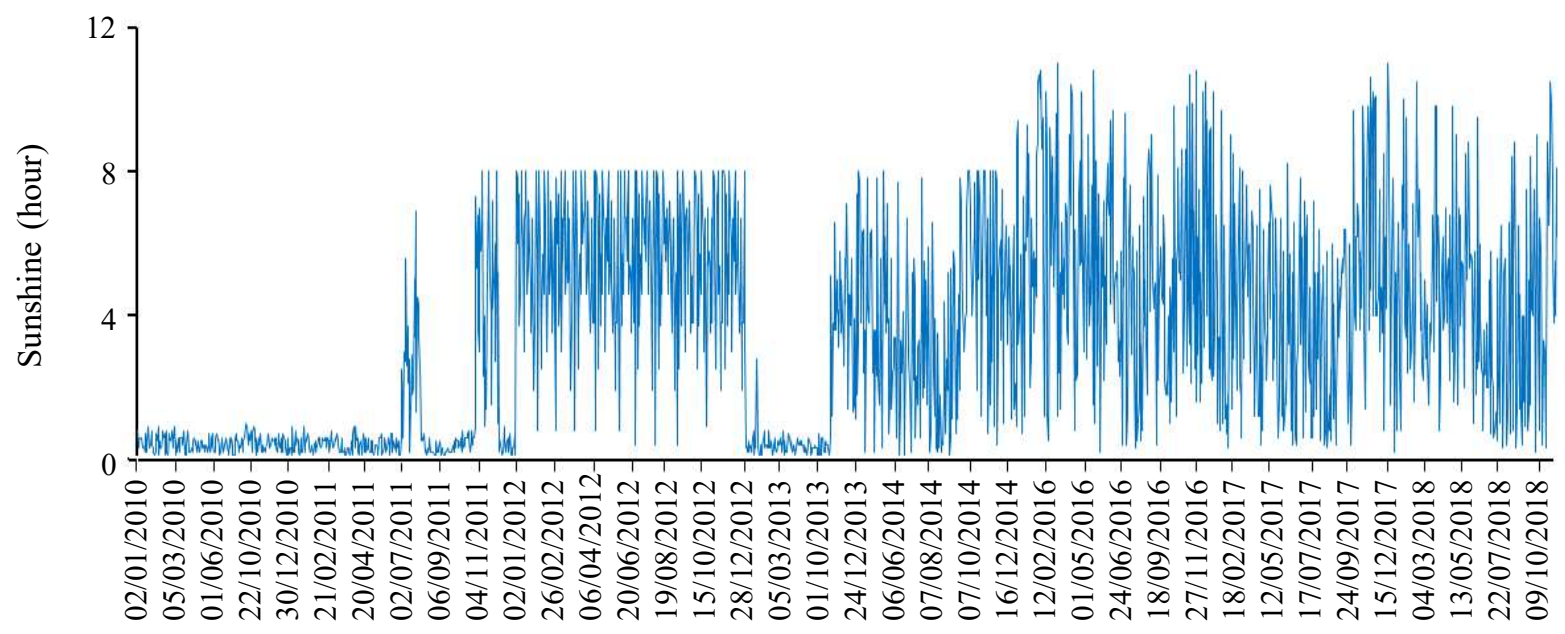

Figure 7. Sunshine duration recording in Torea stations - Fakfak.

bias $(\mathrm{RB})=0$, mean bias factor $(\mathrm{MBF})=1$, and root mean square error $(\mathrm{RMSE})=0$ (Omranian et al. 2018).

\section{RESULTS AND DISCUSSION}

Generally, evapotranspiration data in West Papua extracted from MODIS global evapotranspiration product is not well distributed. Besides, evapotranspiration data from MODIS global evapotranspiration is overestimated compared to climate data analysis. The high cloud cover throughout the year in West Papua affects solar radiation duration. Figure 4 shows the spatial distribution of evapotranspiration derived from MODIS global evapotranspiration. Figure 5 to figure 7 shows the sunshine duration in West Papua from 2010 to 2018 .

Table 1. Statistical performance of MODIS global evapotranspiration compared with climate data analysis.

\begin{tabular}{lcccc}
\hline \multicolumn{1}{c}{ Index } & St. Ransiki & St. Seigun & St. Torea & Average \\
\hline Mean Error (ME) & 0.85 & 0.08 & 1.05 & 0.66 \\
Relative Bias (RB) & 0.29 & 0.03 & 0.48 & 0.27 \\
Mean Bias Factor (MBF) & 0.77 & 0.97 & 0.68 & 0.81 \\
Root Mean Square Error (RMSE) & 1.06 & 0.46 & 1.29 & 0.94 \\
\hline
\end{tabular}

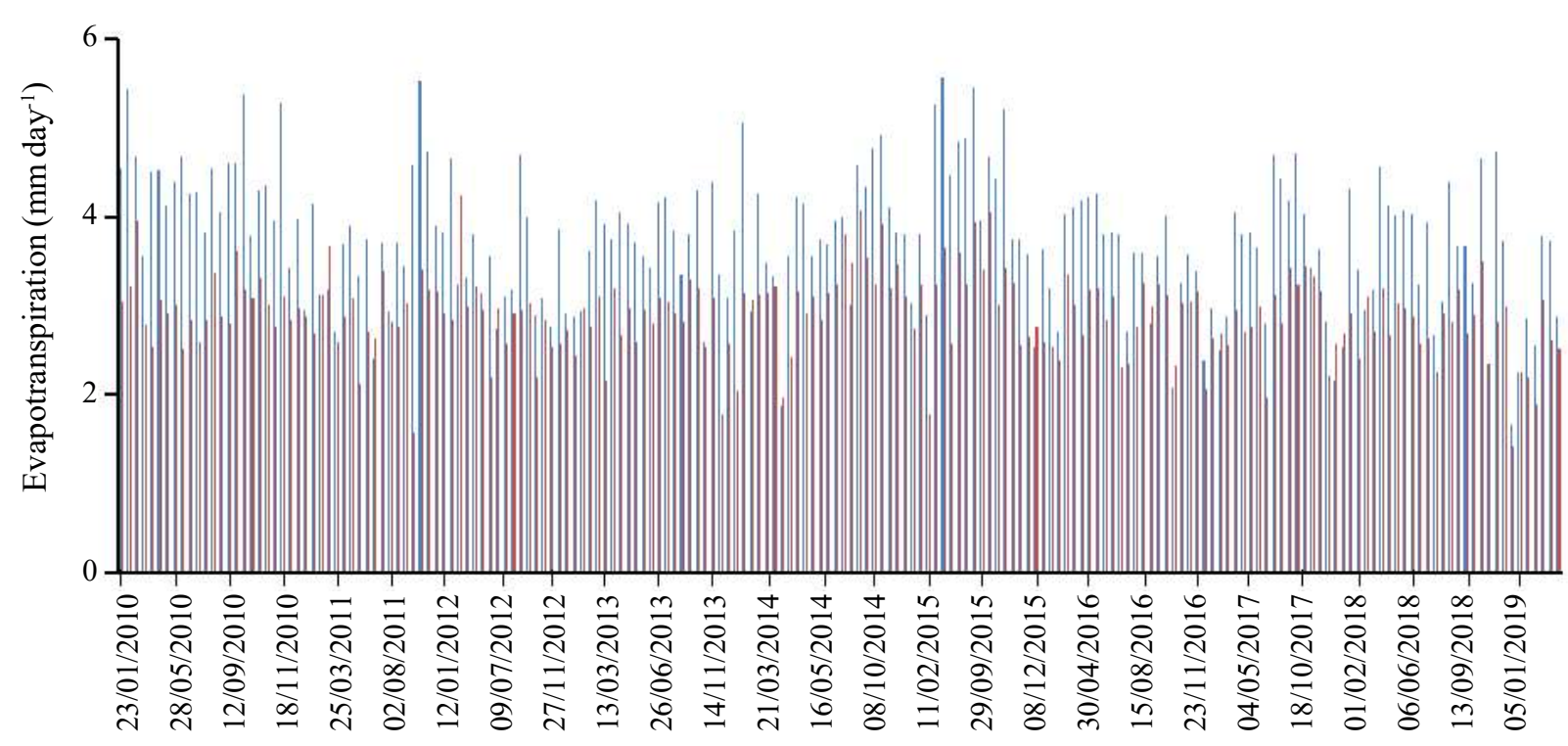

Figure 8. Comparison of MODIS global evapotranspiration with st. Ransiki climate data analysis. MODIS Global Evapotranspiration: C, Climate Data Analysis : 


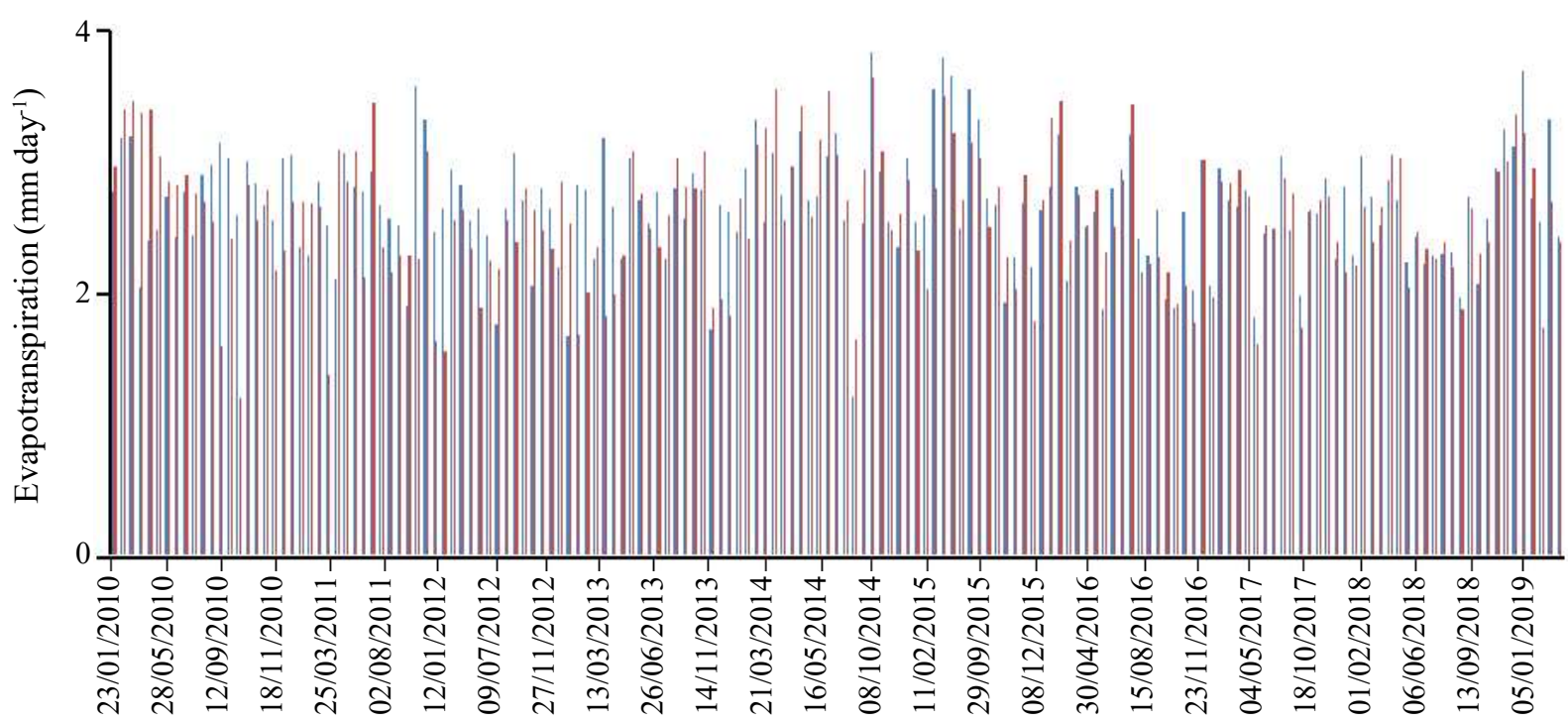

Figure 9. Comparison of MODIS global evapotranspiration with st. Seigun climate data analysis. MODIS Global Evapotranspiration: , Climate Data Analysis :

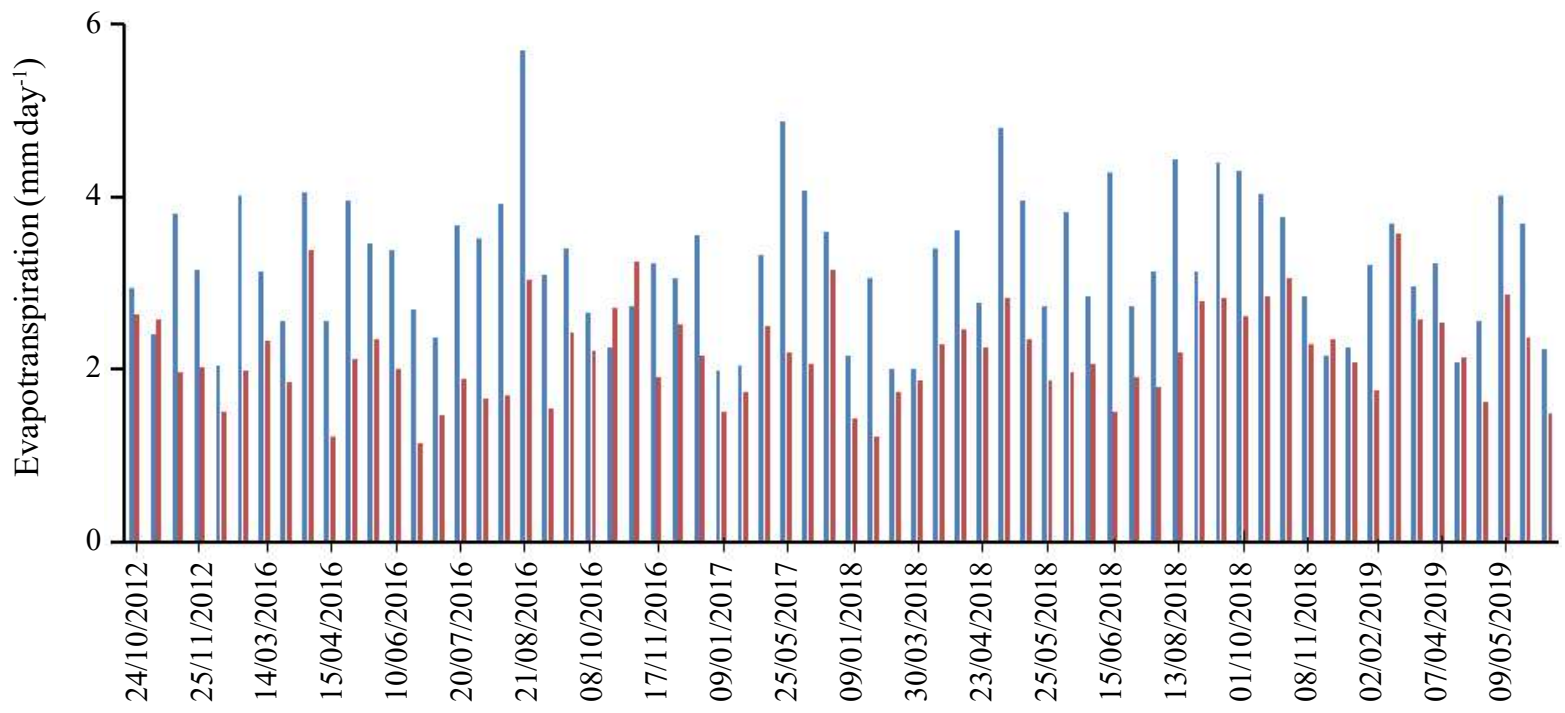

Figure 10. Comparison of MODIS global evapotranspiration with st. Torea climate data analysis. MODIS Global Evapotranspiration: Climate Data Analysis :

Based on statistical analysis, MODIS global evapotranspiration has low error in estimating evapotranspiration in West Papua indicated by $\mathrm{ME}=$ $0.66 \mathrm{~mm} /$ day, $\mathrm{RMSE}=0.94 \mathrm{~mm} /$ day, $\mathrm{RB}=0.27$, and $\mathrm{MBF}=0.81$. It is relevant to a previous study in generating evapotranspiration data in East Java and Monokwari using MODIS global evapotranspiration (Faisol, Budiyono, et al. 2020; Faisol, Indarto et al. 2020). Statistical performance of MODIS global evapotranspiration is shown in Table 1.

Furthermore, a comparison between evapotranspiration from MODIS global evapotranspiration and climate data analysis is shown in Figure 8-10.

\section{CONCLUSIONS}

MODIS global evapotranspiration product can be used as an alternative solution in providing evapotranspiration data in West Papua. The product has a low error and low deviation in estimating evapotranspiration in West Papua compared with climate data analysis.

\section{ACKNOWLEDGEMENTS}

The authors would like thanks to RISTEKDIKTI - Ministry of Research, Technology and Higher Education that financed 
this research by Penelitian Kerjasama Antar Perguruan Tinggi (PKPT) grant, contract no: DIPA-042.06.1.401516/2019 by Papua University and sub-contract no: 198/SP2H/LT/DRPM/2019 by Arif Faisol. Thank also Prof. Indarto and Dr Elida Novita as supervisors from the Faculty of Agricultural Technology, the University of Jember as a partner University.

\section{REFERENCES}

Aguilar AL, H Flores, G Crespo, MI Mar, I Campos and A Calera. 2018. Performance assessment of MOD16 in evapotranspiration evaluation in Northwestern Mexico. Water 10: 14p. https://doi.org/10.3390/ w10070901

Allen RG, LS Pereira, D Raes and M Smith. 1998. Fao Irrigation and Drainage Paper No 56/: Crop Evapotranspiration (1st ed.). FAO. 300p.

Bonemberger BdS, E Mercante, MAV Boas, SC Wrublack and LV Oldoni. 2018. Satellite-based ET estimation using landsat 8 Images and SEBAL model ${ }^{1}$. Rev Ciênc Agron 49: 221-227. https://doi.org/10.5935/ 1806-6690.20180025

Ceron CN, AM Melesse, R Price, SB Dessu and HP Kandel. 2015. Operational actual wetland evapotranspiration estimation for South Florida using MODIS imagery. Remote Sens 7: 3613-3632. https://doi.org/10.3390/rs70403613

Courault D, B Seguin and A Olioso. 2005. Review on estimation of evapotranspiration from remote sensing data: From empirical to numerical modeling approaches. Irrig Drain Syst 19: 223-249.

Faisol A, B Budiyono, I Indarto and E Novita. 2020. Comparison of Terra MODIS Surface Reflectance (TMSR) and Terra MODIS Global Evapotranspiration (TMGE) as Satellite ImageBased Evapotranspiration (ET) in East JavaIndonesia. Agrociencia J 54: 2020-2054.

Faisol A, I Indarto, E Novita and B Budiyono. 2020. An evaluation of modis global evapotranspiration product (MOD16A2) as terrestrial evapotranspiration study in Manokwari-West Papua-Indonesia. ARPN JEng Appl Sci 15: 510-513.

Guzinski R and H Nieto. 2019. Evaluating the feasibility of using Sentinel-2 and Sentinel-3 satellites for highresolution evapotranspiration estimations. Remote Sens Environ 221: 157-172. https://doi.org/10.1016/ j.rse.2018.11.019

Jiang L, S Islam and TN Carlson. 2004. Uncertainties in latent heat flux Measurement and estimation/ : implications for using a simplified approach with remote sensing data. Can J Remote Sens 30: 769787. https://doi.org/10.5589/m04-038

Junior PF, AM Sousa, MI Vitorino, EB De Souza and PJOP De Souza. 2013. Estimativa de evapotranspiração, no leste da Amazônia utilizando SEBAL. Amazonian J Agr Env Sci 56: 33-39.
Kalma JD, TR McVicar and MF McCabe. 2008. Estimating land surface evaporation/ : A review of methods using remotely sensed surface temperature data. Surv Geophys 29: 421-469. https://doi.org/10.1007/ s10712-008-9037-z

Kim HW, K Hwang, Q Mu, SO Lee and M Choi. 2012. Validation of MODIS 16 global terrestrial evapotranspiration products in various climates and land cover types in Asia. KSCE J Civ Eng 16: 229238. https://doi.org/10.1007/s12205-012-0006-1

Li Y, C Huang, J Hou, J Gu, G Zhu and X Li. 2017. Mapping daily evapotranspiration based on spatiotemporal fusion of ASTER and MODIS images over irrigated agricultural areas in the Heihe River Basin, Northwest China. Agric For Meteorol 244-245: 8297. https://doi.org/10.1016/j.agrformet.2017.05.023

Miranda RDQ, JD Galvíncio, MSB de Moura, CA Jones and R Srinivasan. 2017. Reliability of MODIS evapotranspiration products for heterogeneous dry forest/ : A study case of caatinga. Adv Meteorol 2017: 14p. https://doi.org/10.1155/2017/9314801

Mu Q, M Zhao and SW Running. 2011. Improvements to a MODIS global terrestrial evapotranspiration algorithm. Remote Sens Environ 115: 1781-1800. https://doi.org/10.1016/j.rse.2011.02.019

Mu Q, M Zhao and SW Running. 2013. MODIS global terrestrial evapotranspiration (ET) product (NASA MOD16A2/A3): Algorithm Theoretical Basic Document. NASA. 66p.

Nouri H, M Faramarzi, B Sobhani and SH Sadeghi. 2017. Estimation of evapotranspiration based on surface energy balance algorithm for land (SEBAL) using Landsat 8 and MODIS images. Appl Ecol Env Res 15: 1971-1982.

Omranian E, HO Sharif and AA Tavakoly. 2018. How well can global precipitation measurement (GPM) capture hurricanes? case study/: hurricane harvey. Remote Sens: 14p. https://doi.org/10.3390/ rs 10071150

Pierce FJ and P Nowak. 1999. Aspect of precision agriculture. Adv Agron 67: 1-85. https://doi.org/ https://doi.org/10.1016/S0065-2113(08)60513-1

Shekar NCS and L Nandagiri. 2016. Actual Evapotranspiration Estimation Using a PenmanMonteith Model. Int J Adv Agr Environ Engg. 3: 161-164.

Thenkabail P. 2016. Remote Sensing Handbook/ : Land resources monitoring, modeling, and mapping with remote sensing: Vol. II (1st ed.). CRC Press. London. 849p.

WMO [World Meteorological Organization]. 2008. Guide to Hydrological Practices. Volume I: HydrologyFrom Measurement to Hydrological Information. In Journal of the Nepal Medical Association: Vol. I (6th ed., Issue 168). World Meteorological Organization. https://doi.org/10.1080/ 02626667.2011 .546602

Zhang Q. 2016. Precision Agriculture Technology for Crop Farming (1st ed.). CRC Press. London. 368p. 